\title{
Open educational resources in continuing adult education: development in the German-speaking area
}

\author{
Sandra Schön ${ }^{1}$ and Martin Ebner ${ }^{2^{*}}$ (I)
}

\author{
*Correspondence: martin.ebner@ \\ tugraz.at \\ Educational Technology, Graz \\ University of Technology, Graz, \\ Austria \\ Full list of author information is \\ available at the end of the article
}

\begin{abstract}
Open Educational Resources (OER) allow many different uses in educational work that are excluded from traditional materials by copyright laws, such as modifying and republishing existing materials. This article examines the current role of OER in the field of adult education in German-speaking area, especially in Germany, Austria and Switzerland. Although nowadays the topic of digitization is given a high strategic importance in continuing education in Switzerland, OER plays just a subordinate role there.
\end{abstract}

Keywords: Open education, Open educational resources, German speaking countries

\section{Introduction}

The former and basic idea of general adult education institutions in German-speaking Europe was that education has to be openly accessible and for free. The first initiatives, then called "Volksbildung", were free of charge - e.g. libraries and popular science lectures (Dostal, 2008) - and even today lectures, e.g. at Vienna Adult Education Centres, are partly free of charge. Today, however, the courses themselves have to be paid and are not free of charge. Although the Internet would allow to share learning materials for free, copyright and no existing "fair use" regulation limits the use dramatically as well. On the other side, german stakeholders foresee that information technologies and Technology Enhanced Learning (TEL) offerings will be increasingly used in continuing education (e.g. Wuppertaler Kreis, 2014, p.11). With increasing digitization - i.e. increasingly also in continuing vocational training, especially in continuing training in huge companies and in occupations where people work on computers - situations that violate strong copyright law are occurring more and more frequently (cf. Hartmann, 2014). And it is known from surveys that adult educators like to create their own course materials and also use materials from others (cf. Kreitlein \& Newrly, 2015, p. 8). Therefore, the development and availability of so-called "open educational resources" might be of big interest in German speaking countries in the field of adult/continuing education (Ebner et al., 2015).

Open educational resources are teaching and learning materials that are deliberately made freely accessible for use by others. The term "free educational materials" is used synonymously (Bündnis Freie Bildung, 2018). Open educational resources can also be

(c) The Author(s). 2019 Open Access This article is distributed under the terms of the Creative Commons Attribution 4.0 International License (http://creativecommons.org/licenses/by/4.0/), which permits unrestricted use, distribution, and reproduction in any medium provided you give appropriate credit to the original author(s) and the source, provide a link to the Creative Commons license, and indicate if changes were made. 
reproduced, printed, modified and republished (cf. Geser, 2007). In order for this to be legally possible, the materials must be provided with appropriate declarations or, better still, so-called "free" or "open" licensed. Three license options of the Creative Commons licenses are most widespread: CC BY, CC BY-SA and CC 0 (cf. Bündnis Freie Bildung, 2015; Ebner et al., 2016, Schaffert \& Geser, 2008; Schön, Ebner, \& Lienhardt, 2011).

It is to be expected that with the increase in digitization and the resulting increase in awareness and prosecution of copyright infringements, interest in OER and its use will also increase in order to be able to deal with third-party materials in a legally compliant manner. But what is the current status?

\section{Research question and methodology}

This article provides an answer to the following research question: Where do the German-speaking European countries (Germany, Austria and Switzerland) currently stand concerning OER in the field of adult / continuing education?

In this article we like to give an overview of the current status of OER in Germanspeaking European countries. Therefore, we will describe projects and the status quo of OER in continuing education in Germany, Austria and Switzerland. The synopsis is based on preparatory work by other authors (Blees, Deimann, Seipel, Hirschmann, \& Muuß-Merholz, 2015; Kreitlein \& Newrly, 2015; Orr, Neumann, \& Muuss-Merholz, 2017; Tschofen, 2014) and on our own contributions (e.g. Lüthi \& Sterchi, 2015; Schön \& Ebner, 2015; Schön, Kreissl, Dobusch, \& Ebner, 2017; Schön, Rossegger, \& Ebner, 2012), in particular on the compilation of the analysis of OER in Germany commissioned by the German Ministry of Education (Ebner et al., 2015). In addition, developments for Switzerland were added to the contribution (Reimer \& Böller, 2017; Reimer \& Edinger, 2014). We additionally did detailed investigations concerning some milestones in OER-development within these countries.

\section{General OER development in the three countries}

The Journal of the National Agency ("Education for Europe") at the German Federal Institute for Vocational Education and Training (BIBB) contains a longer article on the significance of OER from the perspective of the EU Commission (Bettray, 2014): "The EU Commission particularly emphasizes the systemic level with the demand to adapt the organizational strategies of institutions of general and vocational education and training with regard to IT-supported learning and OER" (Bettray, 2014, own translation). When this contribution was published OER was is not at all a common term amongst adult educators. But, similar as in other countries worldwide, the OER movement started already about 10 years ago with the start of Creative Commons chapters by funding first OER working groups and conference. And overview about these dates is given in Table 1.

Pretty early, and before the start of the Wikipedia project in 2001, the project "Austria-Forum"(www.austria-lexikon.at) was developed from the project "aeiou" (Annotierbares Elektronisches Interaktives Österreichisches UniversalInformationssystem) and offers free content about Austria itself. It consists of four sections and offers more than 33,000 entries about Austria. These originate from an editorial team, which 
Table 1 Milestones in OER-related developments in Austria, Germany and Switzerland

\begin{tabular}{|c|c|c|c|}
\hline & Austria & Germany & Switzerland \\
\hline $\begin{array}{l}\text { First free online content } \\
\text { initiatives }\end{array}$ & $\begin{array}{l}\text { Origins in 1996: } \\
\text { http://www.aeiou.at, } \\
\text { collection of } \\
\text { Austria-related } \\
\text { information }\end{array}$ & $\begin{array}{l}\text { Foundation of the } \\
\text { German-speaking } \\
\text { (not necessarily German) } \\
\text { Wikipedia in } 2001\end{array}$ & $\begin{array}{l}\text { SWITCHcollection - } \\
\text { National Learning } \\
\text { Object Repository } \\
\text { in } 2009\end{array}$ \\
\hline $\begin{array}{l}\text { Funding/Start of Creative } \\
\text { Commons Chapter }\end{array}$ & 2004 & 2007 & 2007 \\
\hline First OER working groups & $\begin{array}{l}\text { Since 2015: OER } \\
\text { working group } \\
\text { at FNMA }\end{array}$ & $\begin{array}{l}\text { Since 2006: } \\
\text { "Bildungsbündnis Open } \\
\text { Content" }\end{array}$ & $\begin{array}{l}\text { About 2010: } \\
\text { OER SiG @ Eduhub }\end{array}$ \\
\hline First conference & $\begin{array}{l}2007 \text { (final OLCOS } \\
\text { conference in Salzburg } \\
\text { named EduMedia) }\end{array}$ & $\begin{array}{l}2007 \text { in Stuttgart } \\
\text { (Open Content) } \\
2013 \text { in Berlin } \\
\text { (Wikimedia) }\end{array}$ & 2019 in Luzern \\
\hline OER policies & $\begin{array}{l}\text { Several OER projects } \\
\text { were funded by the } \\
\text { ministry since the } \\
\text { 2010ies, but their } \\
\text { usage of open license } \\
\text { was not obligatory. In 2015, } \\
\text { the chancellor took OER } \\
\text { explicitly in his digital agenda }\end{array}$ & $\begin{array}{l}2014 \text { funding of two } \\
\text { bigger projects: an } \\
\text { OER portal and a } \\
\text { mapping project, } 2015 \\
\text { funding for several } \\
\text { OER projects }\end{array}$ & $\begin{array}{l}\text { No explicit OER policy or } \\
\text { public funding so far. }\end{array}$ \\
\hline
\end{tabular}

intensively takes care since the 1990ies. Today the platform is well-known as "Austria Forum" and holds more than 1.000.000 digital objects.

Due to different terms for OER within the first years, it is very tricky to research on the history of its development. Austria seemed to be for many years the leading German speaking nation, driven with several bottom-up initiatives as well funded initiatives (the usage of open licenses was voluntary). Germany has caught up with OER in recent years, in particular through specific calls for tenders. In 2007, the EduMedia conference in Salzburg was the first conference in German-speaking Europe. Afterwards, an increase in events on this topic can be observed since 2013, including OER camps and OER festivals, mainly in Germany. Switzerland needed nearly more than one decade longer to organize the first bigger OER conference (2019).

From a political educational view there are some big initiatives of funding of OER in Germany: The working group of representatives of the federal states and the federal government on Open Educational Resources (OER) published a statement in 2014 explicitly calling for an "Information and Coordination Office for OER", "especially for he areas of schools and lifelong learning" (cf. Kultusministerkonferenz und Bundesministerium für Bildung und Forschung (kurz KMK/BMBF), 2015, p. 10). Finally, two major OER projects were funded by the German ministry in 2015, including "Mapping OER" by the Wikimedia Foundation with 600,000 euros (Hochschulforum Digitalisierung, 2016). In addition, in 2017-2018 the OER funding line of the German Federal Ministry of Education and Research ${ }^{1}$ (BMBF) explicitly supported OER continuing education and counselling with 2 million euros.

In Austria, too, OER plays a proven strategic role, particularly in the area of schools and universities; under the last Federal Chancellor Christian Kern, OER 2017 was explicitly mentioned in the national digital agenda. Furthermore, the ministry of science together with national associations published two strategical whitepapers about the use of

${ }^{1}$ https://www.bmbf.de/foerderungen/bekanntmachung-1132.html (2018-02-24) 
"OER in Higher Education". The topic is also present in the area of adult education; the above-mentioned magazine erwachsenenbildung.at and a rather huge online-course called "EBmooc" are funded by a federal ministry. In Switzerland, at least in the german speaking part, there is a lack of comparable public funding programs, and OER also plays a rather subordinate role in government publications or calls for research projects.

\section{OER in continuing education within the three countries}

Within this chapter, we want to give examples of OER within the field of continuing education from Austria, Germany and Switzerland.

\section{Provider and offers of OER in the field of adult education}

In a survey of public libraries in Baden-Württemberg in 2014, no institution stated that it offered OER (Tschofen, 2014, p. 51). Although the public libraries play an important role as places of learning, especially for self-directed learning in leisure time, here, too, more involvement with regard to OER is only slowly emerging. OER have still a difficult position in the area of continuing vocational/company training (cf. Ebner et al., 2015).

In Austria and Germany, adult education associations and platforms are active in the field of OER, e.g. by operating platforms with OER. Two German-language collections of OER materials for adult education have been published under open licenses since 2016: the Austrian magazine "erwachsenenbildung.at" and the portal of the same name "erwachsenenbildung.at" (CC BY) and the German counterpart, the portal "wb-web", initiated by the German Institute for Adult Education together with the Bertelsmann Foundation. A comparable Swiss offer in adult education does not yet exist. OER offers under open CC licenses, which are also interesting for adult educators, can be found in Switzerland, for example, in the area of teacher training. OER can be found on "zebis.ch" and the PHBern "idea sets". Other Swiss services are accessible free of charge or are only released for non-commercial use, although there is often no binding open licensing (see Reimer \& Böller, 2017, p. 88). But there is no special OER offer for adult education.

The following Table 2 tries to give an overview of developments outlined in relation to OER in adult education in the three German-speaking European countries. It shows that whereas in the (10 times bigger than Austria) Germany, OER is a topic in adult education magazines since about 2012, same in Austria. For Switzerland a first finding is from 2018.

Only for a few economic sectors and companies is openness in itself a success factor and value. Probst (2014) names the strengths of open source development as follows:

Table 2 OER in adult/continuing education in Austria, Germany and Switzerland

\begin{tabular}{|c|c|c|c|}
\hline & Austria & Germany & Switzerland \\
\hline $\begin{array}{l}\text { OER platforms for adult/ } \\
\text { continuing education }\end{array}$ & $\begin{array}{l}\text { http://erwachsenenbildung.at } \\
\text { (since } 2016 \text { under CC BY) }\end{array}$ & $\begin{array}{l}\text { http://wb-web.de } \\
\text { (established under } \\
\text { CC BY 2016) }\end{array}$ & No offer. \\
\hline $\begin{array}{l}\text { OER in adult education: } \\
\text { Whitepaper and status } \\
\text { quo analysis }\end{array}$ & Not available so far & $\begin{array}{l}\text { Blees et al. (2015) } \\
\text { Schön, Ebner, } \\
\text { and Schön (2015) }\end{array}$ & Not available so far \\
\hline $\begin{array}{l}\text { OER as topic in adult } \\
\text { education journals }\end{array}$ & Schön et al. (2012) & $\begin{array}{l}\text { Klebl (2012) } \\
\text { Clark (2013) }\end{array}$ & Schön and Ebner (2018) \\
\hline
\end{tabular}


"Openness, trust, transparency, diversity, the courage to innovate and meritocracy are moving to the forefront of an innovative corporate culture." Cogneon $\mathrm{GmbH}$ is still a rare case of a commercial enterprise offering OER. In the Cogneon Wiki, the GmbH presents OER provision as part of its strategy (see Pape, 2013). Other providers of OER for adult education purposes are universities. Within Switzerland, there does not seem to be a single organization within adult/continuing education providing OER on a higher level.

Hirschmann (2015, translation by authors) explains about OER in continuing education: "Strong impulses and initiatives on the topic of OER materials in adult education/ continuing education come from general continuing education and political education. These areas are financed with public funds and see their educational mandate as "education for all", i.e. they want to disseminate their offers as widely as possible and with low hurdles" (Hirschmann, 2015, p. 29). From the perspective of teachers in general continuing education, too, financing is an important criterion for the provision of materials as OER, according to one expert in the analysis of the current situation of OER in Germany - however, the pay of teachers and the promotion of public continuing education are so scarce that they are all competing against each other (cf. Ebner et al., 2015).

\section{Online courses on continuing education as an OER}

In addition, there are numerous OER offers that can be used for further training of adults. Openly licensed courses are a special feature of the OER's continuing education programmes. It is important to note that not every online course or "MOOC" (for "Massive Open Online Course", i.e. open online course for many; see McAuley, Stewart, Siemens, \& Cormier, 2010) is openly licensed. The "open" for MOOCs refers in general only to the absence of formal access conditions; it does not mean that the content of the MOOC is generally freely licensed (cf. Ebner, Kopp, Wittke, \& Schön, 2014). However, the online courses presented below are based exclusively on openly licensed materials, i.e. OER (cf. also Ebner et al., 2015). In particular, the two German-language OER-MOOC platforms, the Austrian platform "imoox.at" (Kopp \& Ebner, 2013) and the course platform of the FH Lübeck "oncampus" (formerly "mooin"), should be mentioned here; both providers cooperate (see MOOChub ${ }^{2}$ ). Adult education institutions have already successfully participated in open licensed MOOCs, for example the Austrian Adult Education Association received a state prize in 2015 for the online course "Gratis Online Lernen" (Ebner et al., 2015; Schön \& Ebner, 2014).

The so-called "EBmooc" for teachers in continuing education was carried out for the first time in 2017 (by the conedu association on the imoox.at platform) and, with more than 1000 graduates, has a wide reach - probably Europe's largest train-the-trainer measurement. The use of OER enabled many uncomplicated cooperations with providers of accompanying classroom events; repetitions of the successful model are planned for the next few years (Ebner et al., 2017) and the EBmooc will be relaunched 2020. The Swiss offer of MOOCs is predominantly made available by universities with the aim of making research-based content from teaching and research available to members of the university and an interested public. However, the offers - among others

${ }^{2}$ see http://www.onlinebynature.com/2015/05/moochub-imoox-und-mooin-gruenden-neues-mooc-netzwerk/ (2015-05-05) 
from the University of Zurich, ETH, University of Geneva or EPFL - are not openly licensed.

\section{Further education offers and research on the topic}

In the publications about OER in continuing education, it is repeatedly pointed out that qualification-offers would be an important measurement to inform people about OER and thus to support its development and use. Among the research projects that specifically deal with OER in continuing education in German-speaking countries is the project "OERup!", which deals with regional adult education initiatives and the situation of OER in the regions (cf. Kreitlein \& Newrly, 2015). In Austria, the research and development project EBmooc is to mentioned here again. No specific research on OER in adult education can be found in Switzerland.

The online courses on open educational resources with the abbreviation "COER" are also relevant in the sense of continuing education and OER, although without the participation of a traditional continuing education institution. When the course was first done in 2013, more than 1000 registered participants were counted, and most will have seen it as part of their continuing vocational training. "COER13.de" was developed and implemented through a cooperation of "e-teaching.org"with other German, Belgian and Austrian institutions (Arnold, Kumar, Schön, Ebner, \& Thillosen, 2015). On the platform "imoox.at", the course has been regularly conducted and updated in a modified form since May 2015. Since the course materials are openly licensed learning videos, all materials remain accessible and usable (Ebner, Lorenz, et al., 2016).

\section{Public recognition of OER with awards within adult education}

The Austrian State Prize for Adult Education 2015 was awarded to the openly licensed online course on the MOOC-platform iMooX.at and the cooperation project "Free Online Learning" with more than 1000 participants in the category "Digital Literacy". In 2017, the Austrian organization CONEDU led the openly licensed online course for digitization in adult education (EBmooc47), which was the largest German-language adult education initiative. More than 3000 registered participants have successfully completed the course. Funding was provided from the Federal Ministry of Education (Ebner et al., 2017). In Germany, a special OER award were installed 2017: At the OER Conference 2017 in Berlin, an OER Award was presented for the best projects in the field of Open Educational Resources in German-speaking countries. The WB-Web platform was awarded in the area of further education. Within Switzerland, we neither found an awarded OER project, nor OER awards.

\section{Interpretation}

To sum up, surprisingly big differences can be stated between OER in adult education in Austria and German on the one side and within Switzerland on the other. Whereas Germany and Austria now already have OER platforms, initiatives and projects for some years now, the first OER conference in Switzerland in January 2019 had a workshop (amongst others) titled with "Does Switzerland also want to promote a culture of openness?" (see conference program). 
The structures of adult education in Germany and its much smaller neighbor Austria are comparable. Both countries are also members of the EU, which has declared OER a strategy (European Commission, 2013). In spite of (partly) the same language, Switzerland differs structurally a lot, so there is no specific association for the so-called "general adult education", the association represents both public and private providers.

In both countries, Germany and Austria, the OER-way happened quite similar. There were some first grassroot-projects. Afterwards the federal ministries got aware of those ones and installed first funding for further projects. In parallel first strategic implementations have been done. Today, OER might be on the way to get recognized by mass of teachers and lecturers and seen as alternative to the strict copyright law in middle Europe. On the other side this article points also out, that it needed more than 10 years to bring the idea of Open Educational Resources to a broad public and it is still far away from a usual practice, especially in adult education.

Acknowledgements

There are no acknowledgements.

Authors' contributions

SS researched about the differences in the countries (Germany, Switzerland, Austria). ME participated in the overall sections (introduction, definition). Both discussed about the final outcome and the conclusion. Both authors read and approved the final manuscript.

Funding

There was no funding at all.

Availability of data and materials

Data sharing is not applicable to this article as no datasets were generated or analysed during the current study. So, we have to state "Not applicable".

Competing interests

The authors declare that they have no competing interests.

Author details

'Salzburg Research, Innovation Lab, Salzburg, Austria. ²Educational Technology, Graz University of Technology, Graz, Austria.

Received: 11 October 2019 Accepted: 5 December 2019

Published online: 21 December 2019

\section{References}

Arnold, P., Kumar, S., Schön, S., Ebner, M., \& Thillosen, A. (2015). A MOOC on open educational resources as an open educational resource: COER13. In J. R. Corbeil, M. E. Corbeil, \& B. H. Khan (Eds.), The MOOC case book: Case studies in MOOC design, development and implementation (pp. 247-258). New York: Linus Learning.

Bettray, S. M. (2014). Open educational resources und informelles Lernen. In Bildung für europa, journal der Nationalen Agentur beim Bundesinstitut für Berufsbildung 21, November 2014. URL: http://www.na-bibb.de/uploads/tx_ttproducts/datasheet/ journal_2014_21.pdf, S. 14 (2015-05-05).

Blees, I., Deimann, M., Seipel, H., Hirschmann, D., \& Muuß-Merholz, J. (2015). Whitepaper open educational resources (OER) in der Weiterbildung / Erwachsenenbildung. Bestandsaufnahme und Potenziale 2015 Ohne Ort: Bertelsmann Stiftung, Internet \& Gesellschaft Co:llaboratory, MinD-Stiftung, Open Knowledge Foundation Deutschland und Technologiestiftung Berlin in Kooperation mit open-educational-resources.de - Transferstelle für OER. URL: http://open-educational-resources.de/wpcontent/uploads/sites/4/2015/02/Whitepaper-OER-Weiterbildung-2015.pdf (2015-05-05).

Bündnis Freie Bildung (2018). Bündnis Freie Bildung. Positionspapier. online available https://buendnis-freie-bildung.de/ wpcontent/uploads/2018/09/B\%C3\%BCndnis-Freie-Bildung-Positionspapier-2018.pdf (last access December 2019).

Clark, A. (2013). Freie Bildungsressourcen im web 2.0: "Nutzer fügen dem web 2.0 wert hinzu". In DIE Zeitschrift für Erwachsenenbildung 2/2013: Erwachsenenbildung 2.0 URL: http://www.die-bonn.de/id/10943 (2015-05-05).

Dostal, T. (2008). Volksbildung - Erwachsenenbildung - Lifelong learning. In O. Kühschelm, E. Langthaler, \& S. Eminger (Eds.), (Hrsg.), Niederösterreich im 20. Jahrhundert. Band 3: Kultur, Wien-Köln-Weimar 2008, S (pp. 73-110).

Ebner, M., Schön, S., Käfmüller, K. (2015). Inverse Blended Learning bei "Gratis Online Lernen" - über den Versuch, einen OnlineKurs für viele in die Lebenswelt von EinsteigerInnen zu integrieren. In: Digitale Medien und Interdisziplinarität. Nistor, N. \& Schirlitz, S. (Hrsg). Waxmann, Medien in der Wissenschaft Bd 68. (pp. 197-206).

Ebner, M., Khalil, M., Schön, S., Gütl, C., Aschemann, B., Frei, W., \& Röthler, D. (2017). How inverse blended learning can turn up learning with MOOCs? (pp. 21-30). Antigua Guatemala: Proceedings of the International Conference MOOC-MAKER 2017. 
Ebner, M., Lorenz, A., Lackner, E., Kopp, M., Kumar, S., Schön, S., \& Wittke, A. (2016). How OER enhance MOOCs - A perspective from German-speaking Europe. In M. Jemni \& M. K. Kinshuk Khribi (Eds.), Open education: From OERs to MOOCs (pp. 205220). Springer Lecture notes in educational technology.

Ebner, M., Köpf, E., Muuß-Merholz, J., Schön, M., Schön, S., \& Weichert, N. (2015). Ist-analyse zu freien Bildungsmaterialien (OER). Die situation von freien Bildungsmaterialien (OER) in Deutschland in den Bildungsbereichen Schule, Hochschule, berufliche Bildung und Weiterbildungx im Juni 2015 band 10 der Reihe "Beiträge zu offenen Bildungsressourcen", herausgegeben. In M. von Ebner \& S. Schön (Eds.), Book on demand. Norderstedt: [Verlag] bzw. frei zugänglich unter. Berlin-Heidelberg: Springer Verlag. http://03r.eu.

Ebner, M., Kopp, M., Wittke, A., \& Schön, S. (2014). Das $O$ in MOOCs - über die Bedeutung freier Bildungsressourcen in frei zugänglichen online-Kursen. In HMD praxis der Wirtschaftsinformatik. Springer. Berlin-Heidelberg: Springer Verlag.

European Commission. (2013). Opening up education: Innovative teaching and learning for all through new technologies and open educational resources, COM/2013/0654 Brussels.

Geser, G. (2007). Open educational practices and resources. OLCOS roadmap 2012. Salzburg: Salzburg Research URL: http:// www.olcos.org/cms/upload/docs/olcos_roadmap.pdf (2015-05-05).

Hartmann, T. (2014). Urheberrecht in der Bildungspraxis: Leitfaden für Lehrende und Bildungseinrichtungen. In Reihe Perspektive praxis. Bielefeld: W. Bertelsmann.

Hirschmann, D. (2015). Akteure mit OER-Aktivitäten. In I. Blees, M. Deimann, H. Seipel, D. Hirschmann, \& J. Muuß-Merholz (Eds. ). Whitepaper open educational resources (OER) in der Weiterbildung / Erwachsenenbildung. Bestandsaufnahme und Potenziale 2015. Ohne Ort: Bertelsmann Stiftung, Internet \& Gesellschaft Co:llaboratory, MinD-Stiftung, Open Knowledge Foundation Deutschland und Technologiestiftung Berlin in Kooperation mit open-educational-resources.de Transferstelle für OER, S. 26-30 URL: http://open-educational-resources.de/wp-content/uploads/sites/4/2015/02/ Whitepaper-OER-Weiterbildung-2015.pdf (2015-05-05).

Hochschulforum Digitalisierung. (2016). BMBF will Informationsstelle für open educational resources (OER) schaffen URL: (https://hochschulforumdigitalisierung.de/de/news/bmbf-informationsstelle-open-educational-resources-oerausschreibung (2018-02-24)

Klebl, M. (2012). Der Wandel der Bedingungen des Lehrens und Lernens: Open educational resources in der Weiterbildung. Sammelwerksbeitrag. Aus: Grundlagen der Weiterbildung. Rechtsquellen, gerichtliche Entscheidungen, Pläne, Stellungnahmen Kommentare. Praxishilfen. Neuwied: Luchterhand.

Kopp, M., \& Ebner, M. (2013). Bildung für alle! Neue gemeinsame Bildungsplattform der Universität Graz und der Technischen Universität Graz, hamburger eLMagazin, 11, Dezember 2013, S (pp. 54-56).

Kreitlein, I., \& Newrly, P. (2015). Regional analysis report Baden-Württemberg, Germany. Open educational resources uptake in adult education, report von OERup!, version 10.4.15. Stuttgart: MFG Innovation Agency Media and Creative Industries URL: http://www.oerup.eu/fileadmin/_oerup/dokumente/need_analysis_report_MFG_Germany1.pdf (2015-05-05).

Kultusministerkonferenz und Bundesministerium für Bildung und Forschung (kurz KMK/BMBF). (2015). Bericht der Arbeitsgruppe aus Vertreterinnen und Vertretern der Länder und des Bundes zu open educational resources (OER) vom 2701. 2015. URL: http://www.bildungsserver.de/pdf/Bericht_AG_OER_2015-01-27.pdf (2015-05-05).

Lüthi, G., \& Sterchi, S. (2015). Open educational resources (OER) - Ein Praxisbeispiel. In Bibliotheksdienst. Band 49, heft 2, S (pp. 184-188).

McAuley, A., Stewart, B., Siemens, G., \& Cormier, D. (2010). Massive open online courses digital ways of knowing and learning, the MOOC model for digital practice URL: http://www.elearnspace.org/Articles/MOOC_Final.pdf (2015-01-15).

Orr, D., Neumann, J., \& Muuss-Merholz, J. (2017). German OER practices and policy: From bottom-up to top-down initiatives UNESCO Institute for Information Technologies in Education.

Pape, K. (2013). Kostenlose Lernmodule von und für Unternehmen im internet Oder: OER für Product- und Business-Learning? Weblogbeitrag vom 24.6.13. URL: https://khpape.wordpress.com/2013/06/24/kostenlose-lernmodule-von-und-furunternehmen-im-internet/ (2015-05-05).

Probst, S. (2014). Was Unternehmen von open source lernen (können). Werte für den Kulturwandel. In S. Krügl, D. Murschall, \& D. M. Richter (Eds.), HR innovation. Gemeinsam Unternehmenskultur umdenken, insight innovation press URL: http://Www. hr-innovation.org/wp-content/uploads/2014/12/Stefan-Probst-Was-Unternehmen-von-Open-Source-lernen-k\%C3\%B6 nnen-HR-Innovation.pdf (2015-05-05).

Reimer, R. T. D., \& Böller, N. (2017). Offene Bildungskultur in der Schweiz - Perspektiven und Herausforderungen. In Synergie. Fachmagazin für Digitalisierung in der Lehre. 4 https://www.digitallernen.ch//wp-content/uploads/ReimerBoeller_2017 synergie04.pdf (2018-03-03).

Reimer, R. T. D., \& Edinger, E.-C. (2014). Open Schweiz - Eine (selbst-) kritische Einschätzung aktueller Initiativen und Projekte zum Themenfeld 'open educational resources' (OER). In P. M. Petra, W. Sützl, T. Hug, P. Grell, \& R. Kammerl (Eds.), MEDIEN - WISSEN - BILDUNG: Freie Bildungsmedien und Digitale archive. Innsbruck: Innsbruck University Press S. 257-276 https:// www.digitallernen.ch//wp-content/uploads/2016/02/freie-bildungsmedien_web.pdf (2018-03-03).

Schaffert, S., \& Geser, G. (2008). Open educational resources and practices. In R. Carneiro \& L. Tarin (Eds.), elearning papers. Promoting innovation in lifelong learning. Special edition 2008 (pp. 14-19). Barcelona. https://www.oerknowledgecloud.org/ archive/media14907.pdf

Schön, S., \& Ebner, M. (2014). Gratis online Lernen. Arbeitsheft. Entwickelt und erstellt in Kooperation des BIMS e.V. (Bad Reichenhall, D) und der TU Graz (Graz, AT) für den Kurs "gratis online Lernen" auf der Plattform imoox.At URL: http://imoox. at/wbtmaster/startseite/download/GoL14_Arbeitsheft.pdf (2015-05-05)

Schön, S., \& Ebner, M. (2018). Offene Bildungsressourcen (OER) in der Weiterbildung. In Education Permanente 2/2018, Praxisbeitrag, S (pp. 42-43)

Schön, S., Kreissl, K., Dobusch, L., \& Ebner, M. (2017). Mögliche Wege zum Schulbuch als open educational resources $(O E R)$. Eine Machbarkeitsstudie zu OER-Schulbüchern in Österreich Band 7 der Reihe "InnovationLab Arbeitsberichte", herausgegeben vom Forschungsbereich InnovationLab der Salzburg Research Forschungsgesellschaft mbH, gleichzeitig erschienen als Band 15 der Reihe "Beiträge zu offenen Bildungsressourcen" (http://o3r.eu) Salzburg: Salzburg Research. URL: http:///3t.eu/oer/images/band15.pdf.

Schön, S., \& Ebner, M. (2015). Warum Trainer_innen und Lehrende offene Bildungsressourcen benötigen. In M. A. Hecke \& D. Röthler (Eds.), Werdedigital.At. Das neue Arbeiten im Netz URL: http://www.werdedigital.at/leitfadenwerdedigital-at/ (2015-05-05) 
Schön, S., Ebner, M., \& Lienhardt, C. (2011). Der wert und die Finanzierung von freien Bildungsressourcen. In Virtual enterprises, Communities \& Social Networks. (2011), S (pp. 239-250).

Schön, S., Ebner, M., \& Schön, M. (2015). Freie Bildungsmaterialien (OER) in der Weiterbildung. In Ist-analyse zu freien Bildungsmaterialien (OER). Die situation von freien Bildungsmaterialien (OER) in Deutschland in den Bildungsbereichen Schule, Hochschule, berufliche Bildung und Weiterbildung im Juni 2015. Berlin: Wikimedia Deutschland e. V.

Schön, S., Rossegger, B., \& Ebner, M. (2012). Offene Bildungsressourcen. In Die Österreichische Volkshochschule - Magazin für Erwachsenenbildung (pp. 13-15) (63) 245 2012. URL: http://files.adulteducation.at/uploads/brigitte_e/OVH_03-2012.pdf (2015-05-05).

Tschofen, F. H. (2014). Open educational resources in Öffentlichen Bibliotheken - Eine analyse von Potenzialen und Grenzen Bachelorarbeit im Studiengang Bibliotheks- und Informationsmanagement an der Hochschule der Medien Stuttgart, 27. 05.2014. URL: http://opus.bsz-bw.de/hdms/volltexte/2014/3939/pdf/Bachelorarbeit.ft021.pdf (2015-05-05).

Wuppertaler Kreis. (2014). Trends 2014: Trends in der Weiterbildung URL: http://www.wkr-ev.de/trends14/trends2014.pdf (2014-05-05)

Publisher's Note

Springer Nature remains neutral with regard to jurisdictional claims in published maps and institutional affiliations.

Submit your manuscript to a SpringerOpen ${ }^{0}$ journal and benefit from:

- Convenient online submission

- Rigorous peer review

Open access: articles freely available online

- High visibility within the field

- Retaining the copyright to your article

Submit your next manuscript at $>$ springeropen.com 